\title{
POLA KERJA PATRON KLIEN PADA PEMILIHAN KEPALA DAERAH DI DESA LALINGATO KECAMATAN TIRAWUTA KABUPATEN KOLAKA TIMUR TAHUN 2015
}

\author{
Risky Amelia', Eka Suaib ${ }^{2}$, Rahman $^{3}$ \\ Universitas Halu Oleo, riskykymeng@gmail.com, Kendari, Indonesia \\ Universitas Halu Oleo, ekasuaib1966@gmail.com, Kendari, Indonesia \\ Universitas Halu Oleo, rahman@gmail.com, Kendari, Indonesia
}

\begin{abstract}
ABSTRAK
Tujuan yang ingin dicapai dalam penelitian ini adalah untuk mengetahui bagaimana pola kerja patron klien pada Pemilihan Kepala Daerah di Desa Lalingato Kecamatan Tirawuta Kabupaten Kolaka Timur tahun 2015. Metode Penelitian yang digunakan adalah jenis penelitian kualitatif pendekatan deskriptif. Informan dalam penelitian ini ditetapkan secara purposive (sengaja) yaitu Bupati atau wakil Bupati, Kepala Desa, 2 orang tokoh masyarakat dan 1 masyarakat di desa Lalingato. Data penelitian dikumpulkan menggunakan teknik wawancara dan dokumentasi. Adapun teknik analisis data dalam penelitian ini terdiri dari : reduksi data, penyajian data dan penarikan kesimpulan.

Hasil penelitian menunjukkan bahwa pola kerja patron klien akan bekerja apabila ada kepentingan pribadi didalamnya, dimana patron disini memberikan bantuan,keuntungan dan pelindungan terhadap klien yang selanjutnya klien membalas dengan memberikan dukungan umum dan jasa-jasa pribadinya terhadap patron. Patron disini adalah calon Kepala Daerah yaitu pasangan Drs. H. Tony Herbiansyah, M.Si dan Hj. Andy Merya Nur, S.IP yang lebih tinggi sosial ekonominya yang kemudian membangun relasi dengan dengan klien yang kedudukan sosial ekonominya lebih rendah yaitu Pak Ramadhan selaku Kepala Desa Lalingato tahun 2015, dimana pada Pemilihan Kepala Daerah Kolaka Timur tahun 2015 yang diikuti oleh 4 pasangan calon saat itu dimenangkan oleh pasangan calon nomor urut 2 yakni $\mathrm{H}$. Tony Herbiansyah dan $\mathrm{Hj}$. Andy Merya Nur dengan perolehan 372 suara $(59,71 \%)$ yang jauh mengungguli 3 pasangan lainnya. Menangnya pasangan $\mathrm{H}$. Tony Herbiansyah pada pilkada Kolaka Timur tahun 2015 di Desa Lalingato itu karena dominannya peranan patron di desa tersebut dengan bekerjanya patron klien sebagain support system yang menimbulkan hubungan resiprokal, walaupun pasangan lain sebenarnya juga menerapkan pola yang sama, namun daya pengaruh ataupun kedalaman pola patron klien pasangan lain tidak sekuat atau sedalam jika dibandingkan dengan yang dilakukan pasangan $\mathrm{H}$. Tony Herbiansyah. Selain itu, media ataupun sarana yang digunakan pasangan lain tidak sebanyak yang dimiliki oleh pasangan $\mathrm{H}$. Tony Herbiansyah dan Hj. Andy Merya Nur.
\end{abstract}

Kata Kunci : Patron Klien, Pemilihan Kepala Daerah.

\section{ABSTRACT}

The aim of this research is to find out how the patron client work patterns in the Regional Head Election in Lalingato Village, Tirawuta Subdistrict, East Kolaka Regency in 2015. The research method used is descriptive qualitative research approach. The informants in this study were determined purposively, namely the Regent or Deputy Regent, the Village Head, 2 community leaders and 1 community in the Lalingato village. Research data were collected using interview and documentation techniques. The data analysis techniques in this study consisted of: data reduction, data presentation and conclusion drawing.

The results show that the patron work pattern of the client will work if there is a personal interest in it, where the patron here provides assistance, benefits and protection to the client to which the client replies by providing general support and personal services to the patron. Patron here is a candidate for the Regional Head, the couple Drs. H. Tony Herbiansyah, M.Sc and Hj. Andy Merya Nur, S.IP, who has a higher socioeconomic level who then builds relationships with clients whose social and economic position is lower, namely Pak Ramadhan as the Head of Lalingato Village in 
2015, where in the East Kolaka Regional Head Election in 2015 was participated by 4 pairs of candidates when it was won by candidate pair number 2 namely $H$. Tony Herbiansyah and Hj. Andy Merya Nur with the acquisition of 372 votes (59.71\%) which far outperformed the other 3 couples. The victory of H. Tony Herbiansyah in the 2015 East Kolaka election in Lalingato Village was due to the dominant role of the patron in the village with the work of the client patron as a support system that gave rise to reciprocal relations, although other couples actually also applied the same pattern, but the influence or depth the patron pattern of the other partner's client is not as strong or as deep as that of H. Tony Herbiansyah's pair. In addition, the media or facilities used by other couples are not as much as those owned by $H$. Tony Herbiansyah and Hj. Andy Merya Nur.

Keywords: Client Patron, Regional Head Election.

\section{PENDAHULUAN}

Pemilihan kepala daerah (Pilkada) di beberapa daerah (kabupaten, kota, provinsi) di Indonesia merupakan wahana bagi masyarakat (provinsi, kabupaten/kota) untuk memilih kepala daerah secara langsung dan diselenggarakan dengan jujur, adil, dan aman. Adanya pemilihan kepala daerah secara langsung tentu saja berimplikasi pada beberapa hal. Pertama, terciptanya kompetisi masing-masing calon kepala daerah. Dalam artian, seorang calon kepala daerah tentu akan melakukan berbagai cara guna memperoleh dukungan suara yang sebanyak-banyaknya dari masyarakat. Kedua, memberikan hak penuh kepada masyarakat sebagai pemilih langsung. Ini berarti masyarakat memiliki kebebasan yang relatif otonom dalam menentukan pilihannya. Pilihan masyarakat bisa saja didasari pertimbangan-pertimbangan tertentu seperti status sosial, figur yang mencalonkan, materi kampanye, dan calon yang kharismatik.

Sehingga dalam realitasnya tidak jarang ditemukan permasalahan disana sini. Permasalahan yang kemudian muncul adalah timbulnya berbagai kepentingan politik dalam ajang pemilihan kepala daerah. Seperti fenomena yang terjadi di Desa Lalingato Kecamatan Tirawuta Kabupaten Kolaka Timur pada pemlihan kepala daerah di Kolaka Timur tahun 2015 salah satu calon Bupati melakukan pendekatan dengan Kepala Desa untuk mendapatkan suara. Pola hubungan tersebut adalah hubungan Patron Klien dimana calon Bupati sebagai Patron (seseorang yang memiliki kekuasaan, wewenang dan pengaruh) dan Kepala Desa disini sebagai Klien (seseorang yang memberikan loyalitas dalam bentuk dukungan suara).

Kehidupan masyarakat tentu akan terwujud beragam pola atau bentuk hubungan (relasi). Hubungan-hubungan tersebut menjadi dan terjalin sedemikian rupa dikalangan masyarakat sehingga terus berlangsung dan tidak pernah berhenti. Salah satu relasi yang dipelajari dalam mata kuliah Sistem Politik Indonesia adalah hubungan patron-klien atau di Indonesia lazim disebut sebagai hubungan bapak-anak ataupun induk semang-anak buah. Istilah "patron" berasal dari ungkapan bahasa Spanyol yang secara etimologis berarti "seseorang yang memiliki kekuasaan (power), status, wewenang dan pengaruh". Sedangkan "klien" berarti "bawahan atau orang yang diperintah atau disuruh”. Menurut Wolf (1984 : 13) mengatakan bahwa hubungan patron klien merupakan salah satu bentuk hubungan pertukaran yang khusus dimana kedua belah pihak, yang menjadi pihak status, 
kekayaan dan kekuatan yang lebih tinggi disebut superior atau patron dan yang lebih rendah disebut imferior atau klien.

Scott (1972: 178), mengungkapkan bahwa hubungan Patron-Klien (Patron-Client Relationship) adalah hubungan atau ikatan antara dua pihak yang menyangkut seperangkat atau sejumlah hubungan pertemanan, bahwa orang yang menggunakan pengaruh atau sumber-sunber dayanya (resources), terutama yang bersifat ekonomis yang dimilikinya, memberikan perlindungan dan keuntungan kepada pihak atau orang yang status ekonomisnya rendah, dalam hal ini Klien. Sebaliknya, Klien tersebut memberikan imbalannya berupa loyalitas dalam bentuk dukungan suara termasuk pelayanan-pelayanan yang bersifat personal atau pribadi terhadap Patron

Salah satu contohnya yakni Fenomena politik dalam Pemilihan Umum Kepala Daerah (Pemilukada) di Kabupaten Kuantan Singingi yang dilaksanakan pada bulan April 2011 yang lalu (Riau Pos, Jum'at 15 April 2011). Hubungan Patron-Klien dalam fenomena politik pada pemilihan umum kepala daerah (pemilukada), H. Sukarmis sebagai Patron (seseorang yang memiliki kekuasaan, wewenang, dan pengaruh) dan tokoh etnis Jawa sebagai Klien (bawahan). H. Sukarmis memberikan perlindungan keamanan, bantuan ekonomi dan mengintensifkan pembangunan terhadap etnis Jawa. Tahap selanjutnya Etnis Jawa tersebut memberikan loyalitas dalam bentuk dukungan hak suara, kesetian menjadi tim sukses serta penghormatan secara mendalam terhadap H. Sukarmis pada Pemilihan Umum Kepala Daerah (pemilukada) tersebut.

Keberadaan Kepala Desa seperti di Desa Lalingato Kecamatan Tirawuta Kabupaten Kolaka Timur, cenderung masih terikat oleh nilai-nilai lama yakni tradisi dan ikatan kulturalnya. Pemilihan Bupati dan Wakil Bupati yang berlangsung di Kabupaten Kolaka Timur ini menarik untuk dicermati karena eksistensi Kepala Desa sebagai bagian yang tak terpisahkan dari masyarakat juga merupakan bagian dari partisipasi politik. Bercermin pada ajang pilkada yang telah bergulir di daerah lain, tampaknya bahwa mesin politik partai politik bukanlah satu-satunya penyokong kemenangan. Dalam hal ini, kualitas dan rekam jejak selama ini menjadi acuan popularitas tokoh-tokoh yang bersaing dalam kontestasi politik lokal. Disisi lain, bagi Kepala Desa di Desa Lalingato Kecamatan Tirawuta Kabupaten Kolaka Timur selain kualitas serta rekam jejak pemimpin selama ini, ikatan etnisitas dan kekerabatan masih sangat kental. Faktor-faktor semacam ini secara langsung memberi celah bagi peranan patron sebagai pengarah opini publik yang potensial di ranah politik. Melihat lebih seksama kontestasi politik lokal dalam pilkada Bupati dan Wakil Bupati yang berlangsung di Kabupaten Kolaka Timur tahun 2015, Kepala Desa masih sangat berpengaruh terhadap pilihan politik masyarakatnya. Seperti fenomena yang terjadi di Desa Lalingato Kecamatan Tirawuta Kabupaten Kolaka Timur, pada saat pemilihan Kepala Daerah tahun 2015 pasangan calon yang melakukan pendekatan langsung atau terjun kemasyarakat yakni pasangan calon nomor urut 4. Wahyu-Idul Fitri dengan perolehan 238 suara $(38,20 \%)$, sedangkan pasangan calon yang melakukan pendekatan dengan Kepala Desa yakni pasangan calon nomor urut 2. Tony-Andi Merya dengan perolehan 372 suara $(59,71 \%)$. Keadaan tersebut sehingga penulis tertarik untuk melakukan penelitian dengan judul 
"Pola Kerja Patron Klien Pada Pemilihan Kepala Daerah di Desa Lalingato Kecamatan Tirawuta Kabupaten Kolaka Timur Tahun 2015" karena penulis melihat adanya hubungan patron-klien antara Kepala Desa dengan salah satu bakal calon Bupati Kolaka Timur Periode 2016-2021 yang pada saat itu diadakan pada tanggal 9 desember 2015 yang salah satunya dilaksanakan di Desa Lalingato Kecamatan Tirawuta Kabupaten Kolaka Timur.

Adapun rumusan masalah dalam penilitian ini adalah bagaimana pola kerja patron klien pada Pemilihan Kepala Daerah di Desa Lalingato Kecamatan Tirawuta Kabupaten Kolaka Timur tahun 2015? Tujuan yang ingin dicapai dalam penelitian ini adalah untuk mengetahui bagaimana pola kerja patron klien pada Pemilihan Kepala Daerah di Desa Lalingato Kecamatan Tirawuta Kabupaten Kolaka Timur Tahun 2015. Terdapat dua manfaat dalam penelitian ini yaitu manfaat akademis dan Praktis yaitu manfaat akademis (Hasil penelitian ini diharapkan dapat memberikan informasi dan menjadi bahan bacaan kepada para pembaca terutama di Jurusan Ilmu Politik terkait bagaimana pola bekerjanya patron klien pada saat Pemilihan Kepala Daerah) dan manfaat praktis (Hasil penelitian ini dapat memberi wawasan kepada masyarakat tentang bagaimana pola bekerjanya patron klien pada saat Pemilihan Kepala Daerah).

\section{METODE PENELITIAN}

\section{Tipe Penelitian}

Penelitian ini menggunakan metode kualitatif dengan menggunakan pendekatan deskriptif karena penulis melakukan pengamatan guna memahami suatu fenomena dengan lebih mendalam terkait adanya pengaruh kepala desa dalam pemilihan kepala daerah di Desa Lalingato Kabupaten Kolaka Timur. Tipe pendekatan deskriptif berusaha menggambarkan suatu gejala sosial. Dengan kata lain penelitian ini bertujuan untuk menggambarkan keadaan suatu objek penelitian yang tengah berlangsung pada saat studi maupun sebelumnya.

Penelitian ini dilakukan di Desa Lalingato, Kecamatan Tirawuta, Kabupaten Kolaka Timur. Terkait pemilihan lokasi, Penulis tertarik melakukan penelitian di Desa Lalingato karena dari 16 desa di Kecamatan Tirawuta, pola kerja patron klien lebih menonjol terjadi di desa tersebut dibandingkan dengan desa yang lainnya. Dengan demikian, pertimbangan pemilihan lokasi penelitian berdasarkan pada pertimbangan akademis dimana ada keterkaitan fenomena yang terjadi dengan pembahasan

Penentuan informan ini dilakukan dengan teknik purposive sampling. Menurut Sugiyono (2008: 218) purposive sampling adalah teknik pengambilan sampe; sumber data dengan pertimbangan tertentu yakni sumber data dianggap paling tahu tentang apa yang diharapkan, sehingga mempermudah peneliti menjelajahi obyek dan situasi social yang sedang diteliti, yang menjadi kepeduliaan dalam pengambilan sampel penelitian kualitatif adalah tuntasnya pemerolehan informasi dengan keragaman variasi yang ada, bukan pada banyak sampel sumber data. 


\section{PEMBAHASAN}

\section{Pola Kerja Patron Klien}

\section{Patron}

\section{Memberikan Bantuan}

Pemberian bantuan juga merupakan salah satu faktor penting dalam hubungan patron klien yang terjadi antara salah satu calon kepala daerah (patron) dengan Kepala Desa Lalingato (klien) yang dimana mereka memiliki hubungan kekerabatan dan hubungan kerja pada saat patron tersebut merupakan PJ Bupati, bantuan yang dimaksud disini berupa pemberian barang dan uang tunai yang akan dibagikan kemasyarakat dan disumbangkan untuk masjid di desa tersebut. Selain uang tunai ada juga janji-janji pemberian proyek dan hak-hak istimewa lainnya jika Kepala Desa (klien) bisa memenangkan paslon (patron) tersebut di Desa Lalingato pada saat Pemilihan Kepala Daearah di Kolaka Timur tahun 2015.

Seperti yang dikatakan oleh Riska Sari selaku masyarakat di Desa Lalingato, yang mengatakan bahwa :

"Yang saya terima saat pilkada 2015 itu sekitar 150ribu dari tim suksesnya Pak Tony (patron) yang kebetulan kakak saya adalah salah satu tim suksesnya. Kalau paslon lain saya tidak tahu berapa nominalnya". (wawancara 30 Juli 2019)

Kemudian ditambahkan lagi oleh Pak Marjunus sealku masyarakat sekaligus pengusaha lokal di Desa Lalingato dengan pendapat yang berbeda, beliau mengatakan :

"Seingat saya waktu itu serangannya pak Tony (patron) 200ribu saya terima, dan istri saya yang kebetulan timnya Wahyu (paslon nomor urut 4) seperti beragam, ada yang 100ribu ada juga 150ribu. Kalau paslon lain nominalnya sama saja rata-rata 100ribu atau mungkin ada yang 50ribu sehingga suaranya sedikit". (wawancara 13 agustus 2019)

Dari hasil wawancara diatas penulis dapat menyimpulkan bahwa masyarakat disini sangat terbuka terkait dalam memaparkan bentuk dari pemberian bantuan yang diberikan oleh masing-masing tim sukses pasangan calon pada Pemilihan Kepala Daerah di Koltim tahun 2015. Masyarakat juga tidak segan menyebutkan nama pasangan calon yang membagikan dan berapa besar nominal uang yang diterima waktu itu, dimana saat itu paslon nomor urut 2 (patron) merupakan paslon yang serangannya lebih tinggi dibandingkan paslon yang berkompetisi lainnya.

Pemberian bantuan memang tidak dapat dihindari ketika demokrasi prosedural seperti Pemilihan Kepala Daerah ini bergulir. Hal ini memang masih dijadikan strategi masing-masing pasangan calon untuk melakukan pendekataan dengan tokoh-tokoh masyarakat atau orangorang yang berpengaruh di desa tersebut seperti Kepala Desa, selain itu dengan melihat kondisi ekonomi masyarakat yang terbatas memang memungkinkan efeknya untuk mempengaruhi masyarakat menyangkut pilihan politik dijatuhkan. 


\section{Memberikan Keuntungan}

Pada saat pemilihan Kepala Derah tahun 2015 di Desa Lalingato kemarin itu terjadi pemberian keuntungan oleh patron terhadap klien yang dimana hal itu merupakan stimulus untuk menguatkan patron di desa tersebut, yang kemudian dibalas dengan imbalan dari klien berupa loyalitas dalam bentuk dukungan suara agar memenangkan paslon tersebut dalam pilkada Kolaka Timur tahun 2015 lalu. Keuntungan yang kemudian diterima Kepala Desa disini berupa proyek dan hak istimewa lainnya.

Hasil wawancara dengan Pak Ramadhan selaku Kepala Desa Lalingato (klien) pada saat itu yang mengatakan bahwa :

"Proyek yang saya terima waktu itu kurang lebih 15 sampai 20 persen dari tiap proyek. Seperti pembangunan 4 deker di rumah jabatan Wakil Bupati yah saya dapat 20 persen dari anggaran 200 juta, kalau rata-rata bangunan seperti pos jaga di rumah jabatan Wakil Bupati waktu itu sekitar 15 persen dari anggaran 100 juta". (wawancara 9 Agustus 2019)

Keuntungan yang diberikan si patron terhadap klien juga masih dirasakan sampai tahun 2019 walaupun si klien sudah bukan lagi Kepala Desa namun hubungan kekerabatan yang telah dibangun rupanya memberikan keuntungan yang berjangka panjang terhadap si klien, selain itu keuntungan yang dirasakan masyarakat sesuai janji si patron pada saat penyampaian salah satu programnya untuk menjadikan desa tersebut sebagai pusat perkantoran dan pemerintahan juga ditepati, dimana hal itu sangat membantu ekonomi masyarakat yang membuka usaha rumah makan, tempat fotocopy dan juga tersedianya lowongan pekerjaan. Desa yang tadinya sunyi juga sudah mulai berkembang, tertata dan ramai.

\section{Memberikan Perlindungan ( jaminan dari patron )}

Memberikan perlindungan yang dimaksud disini yaitu adanya perlakuan khusus si patron terhadap klien yang telah membantu patron dalam memenangkannya di Desa Lalingato pada pilkada Kolaka Timur tahun 2015. Perlakuan khusus yang dijanjikan pada saat itu salah satunya adalah membantu segala kebutuhan si klien dalam pemilihan Kepala Desa berikutnya dan menjamin si klien agar terpilih kembali, meskipun pemilihan Kepala Desa melalui proses politik hanya saja ada perlindungan-perlindungan politik tertentu yang dilakukan patron terhadap kliennya.

Perlindungan politik/perlakuan khusus yang dijanjikan patron terhadap klien pada saat itu merupakan tawaran yang menarik namun masih jadi bahan pertimbangan si klien. Terbukti saat jabatan klien sebagai Kepala Desa yang berakhir pada tanggal 19 desember 2017 dan digantikan oleh Pak Amirullah sebagai PJ Kepala Desa dengan masa jabatan 1 tahun. Kemudian diadakan pilkades pada desember 2018 dengan 2 calon kandidat yaitu Bapak Yusuf BA dan Bapak Dodi Hasril, pilkades saat itu dimenangkan oleh Bapak Yusuf BA yang kemudian dilantik pada januari 2019. 
Pada saaat itu klien tidak mencalonkan lagi sebagai Kepala Desa yang kedua kalinya dengan alasan sibuk dengan pekerjaannya sebagai pemborong dan sedang menyelesaikan pembangunan rumahnya, yang nantinya akan ribet jika menjadi Kepala Desa dimana ada banyak tekanan dari pusat maupun dari masyarakatnya sendiri seperti yang dia rasakan sebelumnya saat menjadi Kepala Desa di Desa Lalingato saat itu, beliau merasa hal itu sudah cukup menjadi pengalamannya saja dan biarkan masyarakaat baru lainnya yang melanjutkan perjalanannya membangun desa tersebut agar menjadi lebih baik lagi dari sebelumnya.

\section{Klien}

\section{Memberikan Dukungan Umum}

Dalam pola kerja patron klien, dukungan umum disini merupakan imbalan yang diberikan klien terhadap patron berupa loyalitas dalam bentuk dukungan suara. Selain itu klien menggunakan atau memanfaatkan posisinya sebagai Kepala Desa yang cukup berpengaruh untuk mengintervensi pilihan masyarakat melalui kepala lingkungan yang cukup berpengaruh di Desa tersebut.

Dari hasil wawancara disimpulkan bahwa Kepala Desa (klien) disini memanfaatkan posisinya sebagai Kepala Desa atau orang yang cukup berpengaruh untuk mengintevensi pilihan masyarakatnya yang dibantu oleh beberapa kepala lingkungan di desa tersebut. Selain itu posisi patron saat itu yang merupakan PJ Bupati Kolaka Timur juga cukup membantu dalam pemenangannya pada pilkada Kolaka Timur tahun 2015.

\section{Memberikan Jasa-jasa Pribadi}

Selain dukungan umum, salah satu imbalan yang kemudian diberikan klien terhadap patron adalah memberikan jasa-jasa pribadi. Selain itu dengan adanya relasi yang terbangun antara patron dan klien disini kemudian membuat klien memiliki loyalis yang tinggi untuk memenangkan patron di desa tersebut.

Dari hasil wawancara penulis dapat menyimpulkan bahwa jasa-jasa pribadi yang diberikan yaitu strategi yang dilakukan Kepala Desa yang hanya mengajak paslon yang dia dukung untuk ikut serta dalam perayaan pesta panen yang diadakan tiap tahunnya dimana hampir seluruh masyarakat di Desa Lalingato ikut serta dalam perayaan tersebut, disitulah peluang besar bagi Kepala Desa dan peranan patron untuk meyakinkan masyarakat terkait program dan visi misi paslon yang dia dukung.

Menangnya patron di Desa Lalingato saat itu karena adanya keterlibatan Kepala Desa dimana dia tidak hanya memberikan dukungan suara saja melainkan juga memberikan jasa-jasa pribadinya ke patron berupa keikutsertaannya dalam setiap sosialisasi dan dalam meyakinkan masyarakat terkait visi-misi dan program patron yang akan menjadikan desa tersebut menjadi pusat perkantoran dan pemerintahan yang kemudian membantu perekonomian masyarakat, dimana akan banyak peluang usaha dan juga lowongan pekerjaan di desa tersebut. 


\section{Hasil Pemilihan Kepala Daerah di Desa Lalingato pada Pemilihan Kepala Daerah KolakaTimur tahun 2015}

\section{Pemilihan Kepala Daerah Secara Langsung di Desa Lalingato Kabupaten Kolaka Timur}

Dalam Pemilihan Kepala Daerah tahun 2015, Desa Lalingato Kabupaten Kolaka Timur menerima empat pasangan calon Bupati/Wakil Bupati Kolaka Timur, yaitu:

1) Pasangan calon no urut 1 yakni H. Syamsu Alam dan Farida Harianti yang diusung oleh PAN dan PBB.

2) Pasangan calon no urut 2 yakni Drs H. Tony Herbiansyah, M.Si dan Hj. Andi Merya Nur, S.IP yang diusung oleh Partai NasDem, Partai Demokrat dan PDIP.

3) Pasangan calon no urut 3 yakni H. Muh Buddu, SE dan H. Ridwan Basnapal, SE yang diusung oleh Partai Hanura, Partai Gerindra dan PPP.

4) Pasangan calon no urut 4 yakni H. Wahyu Ade Pratama Imran, SH dan Idul Fitri Syam yang diusung oleh Partai Golkar, PKS, PKPI, dan PKB.

Untuk mengetahui secara terperinci nama dan partai politik yang mengusung masing-masing pasangan calon dapat dilihat pada tabel berikut ini :

Tabel 5. Nomor Urut dan Nama Pasangan Calon Bupati/Wakil Bupati Kolaka Timur Tahun 2015

\begin{tabular}{cll}
\hline No & \multicolumn{1}{c}{ Nama Pasangan Calon } & \multicolumn{1}{c}{ Partai Politik yang Mengusung } \\
\hline 1. & H. Syamsu Alam dan Farida Harianti, SH & PAN dan PBB \\
2. & $\begin{array}{l}\text { Drs. H. Tony Herbiansyah, M. Si dan } \\
\text { Hj. Andi Merya Nur, S.IP }\end{array}$ & Partai Nasdem, Partai Demokrat dan PDIP \\
3. & $\begin{array}{l}\text { H. Muh Buddu, SE dan } \\
\end{array}$ & H. Ridwan Basnapal, SE \\
4. & $\begin{array}{l}\text { H. Wahyu Ade Pratama Imran, SH dan } \\
\text { Idul Fitri Syam }\end{array}$ & Partai Golkar, PKS, PKPI, dan PKB \\
\hline
\end{tabular}

Sumber : https://pilkada2015.kpu.go.id

Adapun bentuk kampanye yang dilakukan oleh masing-masing calon Bupati/Wakil Bupati relatif sama, yaitu berbentuk :

a. Kampanye dialogis dalam ruang tertutup, dimana paslon bisa mengetahui lebih jauh apa yang dibutuhkan masyarakatnya dan masyarakat bisa mendapat ruang untuk berbicara.

b. Kampanye persuasif (kampanye simpatik), seperti silaturahmi ke tokoh-tokoh masyarakat (alim ulama), dan menghadiri acara pernikahan atau kedukaan.

c. Kampanye terbuka, diadakan dilapangan terbuka yang diisi dengan pidato politik serta visi-misi masing-masing calon dan juru kampanyenya. Biasanya kampanye model ini diikuti dengan pagelaran musik dengan mengundang artis/penyanyi Ibu Kota.

d. Kampanye melalui media sosial misalnya melalui facebook. 
Tabel 6. Perolehan Suara Calon Bupati/Wakil Bupati Kolaka Timur di Desa Lalingato Tahun 2015

\begin{tabular}{llcc}
\hline No & Nama Pasangan Calon & Perolehan Jumlah Suara Sah & Keterangan Presentase \\
\hline 1. & H. Syamsu Alam dan & 5 & 0,80 \\
& $\begin{array}{l}\text { Farida Harianti, SH } \\
\text { Drs. H. Tony Herbiansyah, } \\
\text { M.Si dan }\end{array}$ & 372 & 59,71 \\
& $\begin{array}{l}\text { Hj. Andi Merya Nur, S.IP } \\
\text { H. Muh Buddu, SE dan }\end{array}$ & 8 & 1,28 \\
H. Ridwan Basnapal, SE & & 38,20 \\
4. Wahyu Ade Pratama & Imran, SH dan & 238 & \\
$\quad$ Idul Fitri Syam & & $\mathbf{9 9 \%}$ \\
\hline
\end{tabular}

Sumber: https://pilkada2015.kpu.go.id

Berdasarkan penelusuran penulis, dengan menangnya Tony Herbiansyah pada Pemilihan Kepala Daerah Kolaka Timur tahun 2015 di Desa Lalingato itu karena patron merupakan petahana karena menjadi PJ Bupati atau Bupati sementara di Kolaka Timur, selain itu dominannya peranan patron di desa tersebut dengan bekerjanya patron klien sebagai support system yang menimbulkan hubungan resiprokal sehingga menyebabkan pasangan Tony Herbiansyah dan $\mathrm{Hj}$. Andy Merya Nur memenangkan pertarungan di Desa Lalingato. Patron disini adalah calon Kepala Daerah yang lebih tinggi kedudukan sosial ekonominya yang kemudian membangun relasi dengan klien yang kedudukan sosial ekonominya lebih rendah yaitu Kepala Desa Lalingato.

Selain itu, meskipun paslon lain tidak mendapatkan suara yang melebihi pasangan Tony Herbiansyah dan $\mathrm{Hj}$. Andy Merya Nur namun ketiga pasangan yang lain juga memperoleh suara yang cukup signifikan di lokasi penelitian, hal itu diakibatkan karena pasangan-pasangan yang lain juga mengembangkan pola yang sama dengan pasangan Tony Herbiansyah namun daya pengaruh ataupun kedalaman pola patron-klien pasangan lain tidak sekuat atau tidak sedalam jika dibandingkan dengan yang dilakukan pasangan Tony Herbiansyah, selain itu media ataupun saarana yang digunakan paslon lain tidak sebanyak yang dimiliki oleh pasangan Tony Herbiansyah. Itulah penjelasan mengapa pasangan Tony Herbiansyah dan $\mathrm{Hj}$. Andy Merya Nur dapat memperoleh suara tertinggi pada Pemilihan Kepala Daerah di Desa Lalingato Kecamatan Tirawuta Kabupaten Kolaka Timur tahun 2015.

\section{KESIMPULAN}

Berdasarkan hasil penelitian tentang pola kerja patron klien pada pemilihan kepala daerah di Desa Lalingato Kecamatan Tirawuta Kabupaten Kolaka Timur tahun 2015 yang telah dilakukan oleh penulis, maka dapat disimpulkan bahwa :Patron memperoleh keuntungan dengan adanya dukungan suara yang diperoleh dari klien, Klien memberikan dukungan suara terhadap patron dengan memperoleh keuntungan dalam bentuk pemberian proyek dan Menangnya patron di Desa Lalingato 
saat itu karena adanya keterlibatan Kepala Desa dimana dia tidak hanya memberikan dukungan suara saja, melainkan juga memberikan jasa-jasa pribadinya ke patron yang kemudian menimbulkan hubungan resiprokal yang berjangka panjang antara patron dan klien dan digunakan sebagai stimulus dalam memenangkan patron pada pilkada Kolaka Timur tahun 2015.

\section{DAFTAR PUSTAKA}

Abdul, 2007. Batas-batas Berlakunya Patron-Klien di Kayangan.

Bilatu, Ramlan, 2015. Netralitas Kepala Desa Dalam Penyelenggaraan Pemilihan Bupati Tahun 2015. https://media.neliti.com/media/publications/159223-ID-netralitas-kepala-desa-dalampenyelengga.pdf (diakses pada tanggal 6 november 2018)

Faisal, Sanapiah. 1990. Penelitian Kualitatif (dasar-dasar dan aplikasi). Malang: Ya3 Malang.

Heddy Shri Ahimsa. 2007. Patron \& Klien di Sulawesi selatan. (Yogyakarta : Kepel Pres) edisi terbaru, hal 4

https://pilkada2015.kpu.go.id

Huntington. S. P, Nelson. 1984. Partisipasi Politik Di Negara Berkembang., PT.

Ichsan Fadli, 2016, Hubungan Patron Klien Dalam Pemilihan Kepala Desa Tahun 2015 Di Desa Kampala Kecamatan Arungkeke Kabupaten Jeneponto, Skripsi Jurusan Ilmu Politik Universitas Islam Negri Alauddin, Makassar.

Istiqlal Aryundha, 2015, Hubungan Patron Kien Dalam Pemilihan Kepala Desa Di Kecamatan Tompobulu Kabupaten Gowa, Skripsi Program Studi Ilmu Politik UNHAS, Makassar. Hal 2425.

J. Moleong, Lexy. 2000. Metode Penelitian Kualitatif. Remaja Rosdakarya; Bandung. 167 hlm Jackson, Karl D. 1981. Urbanisasi dan Pertumbuhan Hubungan Patron-Klien; Perubahan Kualitas Komunikasi Interpersonal di Sekitar Bandung dan Desa-Desa di Jawa Barat. Jakarta: Fakultas Ilmu-Ilmu Sosial Universitas Indonesia Jakarta

Jedri dan M. Y Tiya Tinow, 2011, Anaslisis Hubungan Patron Klien Pada Pemilihan Umum Kepala Daerah ( PEMILUKADA) Di Kabupaten Kuantan Singingi Tahun 2011. Hal 11-13.

Jedry, M.Y Tiyas Tinof, 2011. Analisis Hubungan Patron-Klien Pada Pemilihan Umum Kepala Daerah (Pemilukada) Di Kabupaten Kuantan Singingi Tahun 2011.

Joko J. Prihatmoko, 2005, Pemilihan Kepala Daerah Langsung, Pustaka Pelajar, Yogyakarta Lestari, Linayati, 2013. Mengenal Hubungan Patron Klien. http://www.neraca.co.id/article/34731/mengenal-hubungan-patron-klien-1-oleh-linayati-lestarisip-ma-dosen-fisipol-universitas-riau-kepulauan-batam. (diakses pada tanggal 20 oktober 2018) Milles, M.B. and Huberman, M.A. 1984. Qualitative Data Analysis. London: Sage Publication Moh. Nazir, (1988), Metode Penelitian, Ghalia Indonesia, Jakarta.

Ng.Philipus \& Nurul Aini, 2011, Sosiologi dan Politik cetakan ke-4, Jakarta: PT. RajaGrafindo Persada, hal 41-44. 
Pelras, Christian. 1971. Hubungan Patron-Klien Dalam Masyarakat Bugis Makassar, Paris: Tidak Diterbitkan

Ramlan, 2015. Netralitas Kepala Desa Dalam Penyelenggaraan Pemilihan Bupati Tahun 2015.

Scoot, James C, 1983, Moral Ekonomi Petani, (Jakarta: LP3S)

Scott, James C. 1972. 'Patron Client, Politics and Political Change in South East Asia' dalam Friends, Followers and Factions: A Reader in Political Clientalism, Steffen W. Schmidt, James C. Scott dkk. (eds.), Berkeley: University of California Press.

Sugiyono.2006.Metode Penelitian Kuantitatif, Kualitatif dan R \& D.Bandung:Alfabeta.

Suharizal, 2011, Pemilukada Regulasi, Dinamika dan Konsep Mendatang. Jakarta: Rajawali Press.

Undang-Undang No 1 Tahun 2015 Tentang Penetapan Peraturan Pengganti Undang-Undang No 1 Tahun 2014 Tentang Pemilihan Gubernur, Bupati, dan Walikota.

Usman, Suyanto. 2004 Sosiologi; Sejarah, Teori dan Metodologi. Yogyakarta: Center forIndonesian Research and Development (CIReD).

Wolf, Eric. 1984, Kinship, Frrendship And Patron-Client Relations. Michael. 